Situs Jurnal : $\underline{\text { http://ejournal.stiepancasetia.ac.id/index.php/jieb }}$

Jilid 5 Nomor 2 Juli 2019

Hal 151-163

\title{
STRATEGI PEMASARAN HYDRO COCO DENGAN ANALISIS SWOT PADA PT. ENSEVAL PUTERA MEGATRADING TBK CABANG BANJARMASIN
}

\begin{abstract}
Noor Asni Pertiwi*
Abstract: This research to discuss about the correct marketing strategy so that drinking product Isotonik Hydro Coco can to level the analysical to through SWOT. The method that to be used in to do this research is form descriptive with approach quantitatif with to use it primary data that be obtained to through survey. The correct marketing Strategy so that drinking product Isotonik Hydro Coco can to level the analysical to through SWOT, where the analysical result that be done to show Hydro Coco position to PT. Son Enseval Megatrading Branch Tbk Banjarmasin putted to spot $(0.49 ; 0.59)$ until the strategy that to be used is to do product diversificasion/market, with way to use it every the strength that to be have to to exploit it range opportunities long and to respect every the various ofs that exist
\end{abstract}

\section{Keywords: Marketing Strategy, SWOT}

Abstrak: Penelitian ini membahas tentang strategi pemasaran yang tepat agar produk minuman Isotonik Hydro Coco dapat meningkat melalui analisis SWOT. Metode yang digunakan dalam melakukan penelitian ini adalah bentuk deskriptif dengan pendekatan kuantitatif dengan mempergunakan data primer yang diperoleh melalui survey. Strategi pemasaran yang tepat agar produk minuman Isotonik Hydro Coco dapat meningkat melalui analisis SWOT, dimana hasil analisis yang dilakukan menunjukkan posisi Hydro Coco pada PT. Enseval Putera Megatrading Tbk Cabang Banjarmasin terletak pada titik $(0.49 ; 0.59)$ sehingga strategi yang digunakan adalah melakukan diversifikasi produk/pasar, dengan cara menggunakan setiap kekuatan yang dimiliki untuk memanfaatkan peluang-peluang jangka panjang dan untuk menanggulangi setiap ancaman-ancaman yang ada.

Kata kunci : Strategi Pemasaran, SWOT

\section{Latar Belakang}

Fenomena persaingan yang ada telah membuat para pengusaha menyadari suatu kebutuhan untuk mengeksploitasi sepenuhnya aset-aset mereka demi memaksimalkan kinerja perusahaan dan mengembangkan keuntungan kompetitif. Secara umum dapat dikatakan bahwa pemasaran sebagai pola pikir yang menyadari bahwa suatu perusahaan tidak dapat bertahan tanpa adanya transaksi pembelian. Suatu barang atau jasa yang diproduksi perusahaan kepada konsumen dapat bertahan dan bersaing dengan perusahaan lain ketika perusahaan tersebut dapat memasarkan barang atau jasa tersebut.

Keadaan perekonomian saat ini semakin kompleks, masuknya produk asing tanpa batasan akan meningkatkan tingkat persaingan yang tinggi. Hal ini tentu bisa menjadi peluang maupun ancaman bagi perusahaan lokal yaitu peluang bagi perusahaan besar yang mampu beradaptasi dengan perdagangan bebas untuk memasarkan produknya tidak hanya dalam negeri, dan 
ancaman bagi perusahaan yang tidak dapat menyesuaikan diri sementara produk asing terusmenerus masuk ke dalam pasar dalam negeri.

Kebutuhan dan keinginan pasar yang bergerak secara dinamis berubah secara cepat dan terus-menerus, perusahaan harus berpikir lebih kreatif dan kritis dalam memaknai ancaman dan peluang yang ada dipasar melalui pemanfaatan kekuatan dan kapabilitas yang dimiliki perusahaan.

Sektor industri merupakan salah satu sektor penunjang berhasilnya pembangunan ekonomi, dengan demikian tidaklah mengherankan apabila semakin banyak perusahaan yang berdiri. Indonesia dengan sumber daya alam dan sumber daya manusia yang melimpah memberikan daya tarik tersendiri bagi industri asing yang ingin melebarkan usahanya di Indonesia di mana hal tersebut dapat memicu peningkatan kompetisi persaingan. Persaingan industri pangan di Indonesia saat ini menjanjikan suatu peluang dan tantangan baru di mana suatu bisnis makanan dan minuman cepat saji merupakan kebutuhan dan permintaan yang terusmenerus meningkat di pasar.

Kegiatan pemasaran merupakan ujung tombak bagi suatu perusahaan untuk tetap dapat bertahan hidup dengan memiliki strategi khusus dalam memasarkan produknya. Melalui pemasaran suatu perusahaan mampu mendefinisikan keinginan konsumen sehingga penciptaan suatu produk didasarkan pada keinginan pasar dengan tujuan penjualan perusahaan tetap terkendali.

Penjualan produk makanan dan minuman siap saji saat ini semakin meningkat karena masyarakat saat ini cenderung untuk membeli, menggunakan, atau mengkonsumsi hal-hal yang instan. Pada keseluruhan makanan dan minuman terbagi dalam beberapa kategori dan memiliki pertumbuhan yang berbeda-beda, packaged food tumbuh rata-rata $12,6 \%$ per tahun. Sementara itu minuman ringan tumbuh rata-rata $12 \%$ per tahun.

Hydro Coco termasuk minuman isotonik yang digolongkan ke dalam produk sports and energy drink. Minuman Isotonik adalah salah satu produk untuk menghilangkan dahaga dan pada saat manusia dehidrasi dengan tubuh yang lelah, baik setelah beraktifitas rutin maupun olahragawan adapun produk andalan dari PT. Enseval Putera Megatrading Tbk Cabang Banjarmasin yang lagi trend adalah Hydro Coco salah satu produk yang didistribusikan oleh PT. Enseval Putera Megatrading Tbk Cabang Banjarmasin yang berfungsi menghilangkan dehidrasi tubuh setelah tubuh melakukan aktivitas yang padat dan kuat. Pangsa pasar Hydro Coco masih terbilang rendah dibandingkan merek Pocari Sweet, sehingga kegiatan strategi pemasaran $6 \mathrm{P}$ produk Hydro Coco perlu ditingkatkan.

tujuan yang ingin dicapai dalam penelitian ini adalah untuk mengetahui strategi pemasaran yang diterapkan PT. Enseval Putera Megatrading Tbk pada minuman Isotonik Hydro Coco dan untuk memberikan masukan atas strategi pemasaran yang tepat agar produk minuman Isotonik Hydro Coco dapat meningkat melalui analisis SWOT.

\section{Kajian Literatur}

Konsep pemasaran merupakan hal yang sederhana dan secara intuisi merupakan filosofi yang menarik. Konsep ini menyatakan bahwa alasan keberadaan sosial ekonomi bagi suatu organisasi adalah memuaskan kebutuhan konsumen dan keinginan tersebut sesuai dengan sasaran perusahaan. Hal tersebut didasarkan pada pengertian bahwa suatu penjualan tidak tergantung pada agresifnya tenaga penjual, tetapi lebih kepada keputusan konsumen untuk membeli suatu produk.

Definisi pemasaran menurut Kasali (2013:53) adalah suatu proses perencanaan dan eksekusi, mulai dari tahap konsepsi, penetapan harga, promosi, hingga distribusi barang- 
barang, ide-ide dan jasa, untuk melakukan pertukaran yang memuaskan individu dan lembagalembaganya.

Menurut Lupiyoadi (2013:31), mengemukakan pemasaran adalah semua kegiatan yang bertujuan untuk memperlancar arus barang atau jasa dari produsen ke konsumen secara paling efisien dengan maksud untuk menciptakan permintaan efektif.

Tujuan pemasaran adalah mengubah orientasi falsafah manajemen pemasaran lain yang ternyata telah terbukti tidak berhasil mengatasi berbagai persoalan, karena adanya perubahan dalam ciri-ciri pasar dewasa ini yang cenderung berkembang. Perubahan tersebut terjadi antara lain karena pertambahan jumlah penduduk, pertambahan daya beli, peningkatan dan meluasnya hubungan atau komunikasi, perkembangan teknologi, dan perubahan faktor lingkungan pasar lainnya.

Kotler dan Keller (2014:35) mengemukakan bahwa pemasaran mempunyai tujuan membangun hubungan jangka panjang yang saling memuaskan dengan pihak-pihak yang memiliki kepentingan utama pelanggan, pemasok, distributor dalam rangka mendapatkan serta mempertahankan referensi dan kelangsungan bisnis jangka panjang mereka.

Alma (2015:5) mengemukakan bahwa beberapa tujuan dari dilakukannya pemasaran adalah :

1. Untuk mencari keseimbangan pasar, antara buyer's market dan seller's market, mendistribusikan barang dan jasa dari daerah surplus ke daerah minus, dan produsen ke konsumen, dari pemilik barang dan jasa ke calon konsumen.

2. Tujuan pemasaran yang utama ialah memberi kepuasan kepada konsumen. Tujuan pemasaran bukan komersial atau mencari laba. Tapi tujuan pertama ialah memberi kepuasan kepada konsumen, Dengan adanya tujuan memberi kepuasan ini, maka kegiatan marketing meliputi berbagai lembaga produsen. Istilah marketing meliputi marketing yayasan, marketing lembaga pendidikan, marketing pribadi, marketing masjid, marketing nonprofit organization. Tujuan pemasaran lembaga-lembaga non profit ini ialah membuat satisfaction kepada konsumen, nasabah, jamaah, murid, rakyat, yang akan menikmati produk yang dihasilkannya. Oleh sebab itu lembaga-lembaga tersebut harus mengenal betul siapa konsumen, jamaah, murid yang akan dilayaninya. Jika konsumen merasa puas, maka masalah keuntungan akan datang dengan sendirinya. Produsen akan memetik keuntungan secara terus menerus, sebagai hasil dari memberi kepuasan kepada konsumennya.

Menurut Lupiyoadi dan Hamdani (2013:70) bauran pemasaran merupakan alat bagi pemasar yang terdiri atas berbagai unsur suatu program pemasaran yang perlu dipertimbangkan agar implementasi strategi pemasaran dan positioning yang ditetapkan dapat berjalan sukses. Menurut Kotler dalam Hurriyati (2015:47) menyatakan bahwa definisi bauran pemasaran ialah sekumpulan alat pemasaran yang dapat digunakan oleh perusahaan untuk mencapai tujuan pemasarannya dalam pasar sasaran. Menurut Hurriyati (2015:48) definisi bauran pemasaran merupakan unsur-unsur pemasaran yang saling terkait, dibaurkan, diorganisir dan digunakan dengan tepat sehingga perusahaan dapat mencapai tujuan pemasaran dengan efektif sekaligus memuaskan kebutuhan dan keinginan konsumen.

Dalam Kotler unsur-unsur dari bauran pemasaran yang sudah ditambah 2P menjadi mega marketing tersebut diantaranya yang sering dikenal dengan sebutan 6P's (the six P's)

1. Produk (Product)

2. Harga (Price)

3. Promosi (Promotion)

4. Tempat (Place)

5. Kekuatan (Power) 
6. Hubungan Masyarakat (Public Relation)

Adapun penjelasan dari uraian diatas adalah sebagai berikut:

1. Produk (Product)

Menurut kotler (2014:101) menyatakan bahwa produk adalah segala sesuatu yang dapat ditawarkan kepasar untuk memenuhi kebutuhan dan keinginan konsumen. Keputusan tentang produk ini mencakup penentuan garansi dan servis sesudah penjualan. Pengembangan produk dapat dilakukan setelah menganalisa kebutuhan dan keinginan pasarnya. Jika masalah ini telah diselesaikannya, maka keputusan-keputusan tentang harga, distribusi dan promosi dapat diambil. Apa yang ditawarkan menunjukan sejumlah manfaat yang dapat pelanggan dapatkan dan pembelian suatu barang atau jasa, sedangkan sesuatu yang ditawarkan itu sendiri dapat dibagi menjadi empat kategori, yaitu :

a. Barang nyata

b. Barang nyata dan disertai dengan jasa

c. Jasa utama yang disertai dengan barang dan jasa tambahan

d. Murni jasa

Untuk merencanakan penawaran produk, pemasaran perlu memahami tingkat produk, yaitu sebagai berikut :

a. Produk Utama atau Inti (Core Brendit) yaitu manfaat yang sebenarnya dibutuhkan dan akan dikonsumsikan oleh pelanggan dari setiap produk.

b. Produk Generik (Generic Product) yaitu produk dasar yang mampu memenuhi fungsi produk yang paling besar (rancang produk minimal agar dapat berfungsi).

c. Produk Harapan (Expected Product) yaitu produk formal yang ditawarkan dengan berbagai atribut dan kondisinya secara normal (layak) diharapkan dan disepakati untuk dibeli.

d. Produk Pelengkap (Augmented Product) yaitu segala macam tambahan dan perubahan yang mungkin dikembangkan untuk suatu produk dimasa mendatang.

Jadi pada dasarnya produk adalah sekumpulan nilai kepuasan yang kompleks. Nilai sebuah produk ditetapkan oleh pembeli berdasarkan manfaat yang akan mereka terima dari produk tersebut.

2. Harga (Price)

Menurut Kotler (2014:101) menyatakan bahwa harga adalah elemen dalam bauran pemasaran yang tidak saja menentukan Profitabilitas tetapi juga sebagai sinyal untuk mengkomunikasikan proporsi nilai suatu produk. Pemasaran produk perlu memahami aspek psikologis dari informasi harga yang meliputi harga referensi, inferensi kualitas berdasarkan harga, dan petunjuk harga. Pada setiap produk atau jasa yang ditawarkan bagian pemasaran berhak meneentukan harga pokoknya. Faktor-faktor yang perlu dipertimbangkan dalam penerapan harga tertsebut antara lain biaya, keuntungan, praktik saingan dan perubahan keinginan pasar. Kebijaksanaan harga ini menyangkut pula penetapan jumlah potongan, mark-up, mark-down, dan sebagainya. Seperti halnya unsur-unsur bauran pemasaran yang lain, diantaranya produk dan promosi harga pun memiliki komponen bauran harga yang terdiri dari:

a. Daftar Harga (Price List), adalah suatu uraian harga yang dicantumkan pada label atau produk. Contohnya badrol harga pada kemasan sampo dan lotion. 
b. Potongan Harga (Discount,) adalah pengurangan dari harga yang normal. Contohnya diskon saat bazzar, diskon saat cuci gudang, diskon saat hari raya dan diskon saat liburan sekolah.

c. Penghargaan atau keringanan (Allowance), keinginan yang dimaksud adalah keringanan pada konsumen untuk cicilan kredit. Contohnya bunga saat kredit motor yang rendah, ciccilan rumah, dan simpan pinjam.

d. Jangka waktu pembayaran (Payment Period), yaitu cicilan kredit sesuai kesepakatan antara penjual dengan pembeli (berhubungan dengan kredit). Contohnya kredit motor yang dibayar 12 kali angsuran dalam 1 tahun, kredit barang elektronik dibayar 6 kali dalam 3 bulan.

e. Syarat-syarat kredit (Credit Tern), adalah sesuatu yang harus dipenuhi konsumen.

\section{Tempat (Place)}

Menurut Kotler (2014:101), Place merupakan saluran yang digunakan oleh produsen untuk menyalurkan produk tersebut dari produsen sampai ke konsumen atau industry pemakaian. Ada tiga aspek pokok yang berkaitan dengan keputusan-keputusan tentang tempat. Aspek tersebut adalah:

a. Sistem transportasi perusahaan, yang termasuk dalam sistem ini abntara lain keputusan dalam pemilihan alat transportasi (pesawat udara, kereta api, kapal, truck, pipa), penentuan jadwal pengiriman, penentuan rute yang harus ditempuh dan seterusnya.

b. Sistem penyimpanan, dalam sistem ini bagian pemasaran harus menentukan letak gudang, jenis peralatan yang dipakai untuk menangani material maupun peralatan lainnya.

c. Pemilihan saluran distribusi, menyangkut keputusan-keputusan tentang penggunaan penyalur (pedagang besar, pengecer, agen, makelar) dan bagaimana menjalin kerjasama yang baik dengan para penyalur tersebut.

4. Promosi (Promotion)

Menurut Kotler (2014 : 510) menyatakan bahwa promosi adalah berbagai cara untuk menginformasikan, membujuk, dan mengingatkan konsumen secara langsung maupun tidak langsung tentang suatu produk atau brand yang dijual. Promosi adalah salah satu bentuk komunikasi pemasaran, sedangkan yang dimaksud dengan komunikasi pemasaran adalah aktifitas pemasaran yang berusaha menyebarkan informasi, mempengaruhi atau membujuk, dan kemudian mengingatkan pasar sasaran atas perusahaan dan produknya, agar bersedia menerima, membeli dan setia pada produk perusahaan yang bersangkutan. Tiga tujuan utama dari promosi adalah sebagai berikut:

a. Menginformasikan, yaitu dapat berupa :

1) Menginformasikan pasar mengenai keberadaaan suatu produk.

2) Memperkenalkan cara pemakai yang baru dari suatu produk yang baru.

3) Menyampaikan perubahan harga kepada pasar.

4) Menjelaskan cara kerja suatu produk.

5) Menginformasikan jasa-jasa yang disediakan oleh perusahaan.

6) Meluruskan kesan yang keliru.

7) Mengurangi ketakutan atau kekhawatiran pembeli.

8) Membangun citra perusahaan.

b. Membujuk pelanggan sasaran, yaitu dapat berupa :

1) Membentuk pilihan merek. 
2) Mengalihkan pilihan ke merek tertentu.

3) Mengubah persepsi pelanggan terhadap atribut produk.

4) Mendorong pembeli ungtuk belanja pada saat itu juga.

5) Mendorong pembeli untuk menerima kunjungan wiraniaga (salesman).

c. Mengingatkan, yaitu dapat berupa :

1) Mengingatkan pembeli bahwa produk yang bersangkutan dibutuhkan dalam waktu yang dekat.

2) Mengingatkan pembeli akan tempat-tempat yang menjual produk perusahaan.

3) Membuat pembeli tetap ingat walaupun tidak ada kampanye iklan.

4) Menjaga ingatan pertama pembeli jatuh pada produk perusahaan.

5. Kekuatan (Power)

Power adalah penggunaan dengan iklan birokrat supaya suatu market (yang tertutup) bisa diakses, sedangkan public relation adalah penggunaan hubungan dengan public (masyarakat) luas supaya mendapat simpati. Jadi power dan public relation adalah seperti kekuatan push and pull yang bisa dipakai untuk melancarkan akses pasar yang tehambat atau bisa diartikan sebagai kemampuan untuk melobby unsur kekuatan organisasi massa. Power atau kekuatan pada pemasaran juga bisa mengarah kepada kekuasaan yang mempunyai nuansa kekuatan organisasi politik, organisasi massa atau kelompok tertentu di masyarakat. Kekuatan politik, hukum dan perundang-undangan dalam lingkungan pemasaran sangat erat hubungannya antara satu dengan yang lainnya. Kekuatan politik seperti suara, pendapat atau pernyataan para elit politik dalam upaya menggalang kekuatan atau dalam menanggapi suatu masalah antara lain, opini masyarakat, kondisi atau sentiment pasar seperti melonjaknya harga-harga, melemahnya nilai tukar rupiah terhadap mata uang asing, merosotnya harga saham, keamanan dunia dan stabilitas. Landasan pola pikir dalam power marketing terletak pada 3 kunci yaitu moving, carring, dan innovating. Moving adalah tumpuan untuk menjawab gelora persaingan dan dinamika permintaan yang selalu bergejolak karena sifat pelanggan yang cepat berubah atau tidak loyal. Sebab itu landasan harus disertai dengan kepedulian kepada pelanggan yang dinamakan carring melalui inovasi (innovation) dibidang strategi.

6. Hubungan Masyarakat (Public Relation)

Public Relation adalah usaha yang dirancang secara terus-menerus dengan sengaja, guna membangun dan mempertahankan pengertian timbal balik antara organisasi dan masyarakatnya. Pendapat ini menunjukkan bahwa public relation dianggap sebuah proses atau aktivitas yang bertujuan untuk menjalin komunikasi antara organisasi dan pihak luar organisasi. Pengertian public relation adalah interaksi dan menciptakan opini public sebagai input yang menguntungkan untuk kedua belah pihak, dan merupakan profesi yang profesional dalam bidangnya karena merupakan faktor yang sangat penting dalam pencapaian tujuan organisasi dengan secara tepat dan dengan secara terus-menerus karena public relation merupakan kelangsungan hidup organisasi yang bersangkutan. Menurut Kotler (2014 : 510) yang pertama kali memunculkan konsep Mega Marketing yang merupakan perpaduan antara kekuatan Public Ralation dan marketing mix. Kemudian muncul kembali dengan istilah Marketing Public Relation, sebagai pengembangan tahap berikutnya dari konsep sebelumnya. Public Relation dapat memperluas perannya dalam bidang pemasaran dan banyak pengelola marketing menerapkan public relation sebagai 
pendukung unsur promosi dalam marketing mix, public relation digunakan dalam perencanaan mencapai sejumlah sasaran, sebagai berikut:

a. Membantu perusahaan dan nama produknya agar lebih dikenal.

b. Membantu mengenalkan produk baru atau peningkatan produk.

c. Meningkatkan suatu produk, seperti dalam menyempurnakan pesan iklan dan promosi dengan menambah informasi baru.

d. Mencari pangsa pasar baru dan memperluas keberadaannya.

e. Memantapkan semua citra yang positif bagi produk dan usahanya.

Banyak perusahaan yang berpaling ke marketing public relations untuk langsung mendukung promosi dan pembentukan citra perusahaan atau produk. Perusahaan tidak hanya harus berhubungan secara kontruktif dengan pelanggan, pemasok, dan penyalur, melainkan juga harus berhubungan dengan sejumlah besar masyarakat yang berkepentingan. Jadi, dapat disimpulkan bahwa Public Relation adalah proses menciptakan berbagai cara pendekatan untuk bisa membangun image/citra yang baik terhadap produk dan jasa dikalangan masyarakat.

Analisis SWOT adalah suatu metode dalam perencanaan stratejik yang dipakai untuk mengidentifikasi 4 faktor utama yang mempengaruhi kegiatan organisasi sepanjang masa. SWOT adalah akronim dari Strenghts (kekuatan), Weaknesses (kelemahan), Opportunity (Peluang), dan Threats (ancaman). Asumsi yang mendasari analisis ini adalah strategi efektif yang diturunkan dari kesesuaian antara sumber daya internal perusahaan meliputi kekuatan dan kelemahan dengan situasi eksternalnya meliputi peluang dan ancaman. Kesesuaian yang baik akan memaksimalkan kelemahan dan ancaman.

Kekuatan merupakan sumber daya atau kapabilitas yang dikendalikan oleh atau tersedia bagi suatu perusahaan yang membuat perusahaan relatif lebih unggul dibandingkan pesaingnya dalam memenuhi kebutuhan pelanggan yang dilayaninya. Kekuatan uncul dari kompetensi, kapabilitas atau sumber daya yang dimiliki perusahaan, yang dapat digunakan sebagai alternatif untuk menangani peluang dan ancaman. Kekuatan (strength) adalah situasi internal organisasi yang berupa kompetensi/kapabilitas/sumberdaya yang dimiliki organisasi, yang dapat digunakan sebagai alternatif untuk menangani peluang dan ancaman.

Kelemahan merupakan keterbatasan atau kekurangan dalam satu atau lebih sumber daya atau kapabilitas suatu perusahaan relatif terhadap pesaingnya, yang menjadi hambatan dalam memenuhi kebutuhan pelanggan secara efektif. Kelemahan muncul dari situasi internal perusahaan dimana kompetensi, kapabilitas atau sumber daya yang dimiliki perusahaan memiliki keterbatasan. Kelemahan (weakness) juga dapat diartikan situasi internal organisasi dimana kompetensi/kapabilitas/sumberdaya orgamisasi sulit digunakan untuk menangani kesempatan dan ancaman.

Matriks SWOT dapat menggambarkan secara jelas bagaimana peluang dan ancaman eksternal yang dihadapi perusahan dapat disesuaikan dengan kekuatan dan kelemahan yang dimilikinya. Matriks ini dapat menghasilkan empat set kemungkinan alternatif strategis.

1. Strategi S-O adalah strategi yang disusun dengan cara menggunakan semua kekuatan untuk merebut peluang.

2. Strategi W-O adalah strategi yang disusun dengan cara meminimalkan kelemahan untuk memanfaatkan peluang yang ada.

3. Strategi S-T adalah strategi yang disusun dengan cara mengunakan semua kekuatan untuk mengatasi ancaman.

4. Strategi W-T adalah strategi yang disusun dengan cara meminimalkan kelemahan untuk menghindari ancaman. 


\section{Metode Penelitian}

Bentuk penelitian yang digunakan dalam skripsi ini yaitu penelitian dalam bentuk deskriptif dengan pendekatan kuantitatif dengan mempergunakan data primer yang diperoleh melalui survey.

Populasi dalam penelitian ini adalah pelanggan tetap (besar) PT. Enseval Putera Megatrading Tbk Cabang Banjarmasin yang telah membeli produk Hydro Coco seperti toko grosir, hipermart, supermarket dan minimarket pada tahun 2018 di Kota Banjarmasin sebanyak 946 tempat. Dalam menentukan sampel, penulis mengambil teknik kemudahan (kebetulan) yang dapat dianggap atau mewakili sampel yang diteliti (random sampling). Penulis mengambil sampel sebanyak 20 orang untuk dijadikan responden seperti pemilik usaha, manager, kepala toko maupun supervisor untuk mengetahui tanggapan terhadap strategi pemasaran minuman Isotonik Hydro Coco.

Jenis data meliputi (a) Data kuantitatif yaitu data yang berbentuk angka yang disajikan dalam bentuk informasi baik secara lisan maupun tulisan. Bentuk data ini berbentuk hasil tanggapan responden. (b) Data kualitatif yaitu data yang diperoleh dari objek penelitian. Bentuk data ini dapat berupa sejarah singkat objek penelitian, visi misi organisasi, deskripsi tugas, dan lain sebagainya.

Sumber data meliputi (a) Data primer adalah data yang diperoleh langsung dari subjek penelitian, dalam hal ini peneliti memperoleh data atau informasi langsung menggunakan instrumen yang telah ditetapkan dan dikumpulkan untuk menjawab dalam masalah pada penelitian ini. (b) Data sekunder merupakan data atau informasi yang diperoleh secara tidak langsung dari objek penelitian yang bersifat publik yang terdiri atas struktur organisasi, dokumen, laporan serta buku yang berkenaan dengan penelitian ini.

Teknik pengumpulan data dilakukan dengan cara metode kepustakaan yaitu cara penelitian untuk menemukan dan mengembangkan suatu pengetahuan dengan melakukan mencari landasan teori yang sumbernya berasal dari buku literatur, surat kabar, jurnal dan lainlain yang berkaitan dengan tujuan penelitian dan metode lapangan adalah cara yang dilakukan oleh penulis dengan melihat dan mencatat data-data serta bahan yang diperlukan dengan terjun langsung ke objek penelitian.

Teknik analisa data yang digunakan dalam penelitian ini adalah secara deskriptif kuantitatif dengan pendekatan analisis SWOT. Matriks SWOT merupakan alat pencocokan yang penting untuk membantu mengembangkan strategi. Melalui matriks SWOT, kita dapat mengetahui secara jelas apa yang menjadi kekuatan dan kelemahan dari perusahaan dalam menghadapi peluang dan ancaman eksternal. Kinerja perusahaan dapat ditentukan oleh kombinasi factor eksternal dan faktor internal perusahaan. Kedua faktor tersebut dapat dipertimbangkan dalam analisis SWOT. Dimana SWOT membandingkan antara faktor eksternal dan faktor internal kekuatan dan kelemahan.

\section{Hasil Penelitian dan Pembahasan}

Strategi pemasaran yang tepat agar produk minuman Isotonik Hydro Coco dapat meningkat melalui analisis SWOT

Identifikasi faktor internal mencakup kekuatan (strengths) dan kelemahan (weaknesses) yang berpengaruh terhadap perkembangan perusahaan. Hasil pembobotan dan pemberian rating dapat dilihat pada tabel 1. Identifikasi faktor eksternal mencakup peluang (opportunities) dan ancaman (threats) yang berpengaruh terhadap perkembangan perusahaan. Hasil pembobotan dan pemberian rating dapat dilihat pada tabel 2. 
Tabel 1. Internal Factory Analysis Summary (IFAS) 4P Hydro Coco PT. Enseval Putera Megatrading Tbk Cabang Banjarmasin

\begin{tabular}{|c|c|c|c|}
\hline Faktor strategi internal & Bobot & Rating & $\begin{array}{c}\text { Skor } \\
\text { (B X R) }\end{array}$ \\
\hline \multicolumn{4}{|l|}{ Kekuatan (Strenght): } \\
\hline $\begin{array}{l}\text { 1. Hydro Coco merupakan minuman air kelapa pertama dalam kemasan } 250 \\
\text { ml dan } 500 \mathrm{ml} \text { yang memiliki } 7 \text { kebaikan }\end{array}$ & 0,13 & 3 & 0,39 \\
\hline $\begin{array}{l}\text { 2. Pembayaran bisa mundur sampai dua minggu untuk batas waktu yang } \\
\text { paling lama }\end{array}$ & 0,16 & 3 & 0,48 \\
\hline 3. Memiliki gudang yang luas untuk melakukan penyimpanan & 0,13 & 3 & 0,39 \\
\hline \multirow[t]{2}{*}{$\begin{array}{l}\text { 4. Pemberian jaminan terhadap produk kembali jika kadaluwarsa dan } \\
\text { pemberian hadiah }\end{array}$} & 0,13 & 3 & 0,39 \\
\hline & & & 1,65 \\
\hline \multicolumn{4}{|l|}{ Kelemahan (Weakness): } \\
\hline $\begin{array}{l}\text { 1. Mempunyai produk yang bervariasi } 250 \mathrm{ml} \mathrm{dan} 500 \mathrm{ml} \text {, kemasan mudah } \\
\text { rusak atau bocor. }\end{array}$ & 0,14 & 3 & 0,42 \\
\hline $\begin{array}{l}\text { 2. Pemberian diskon hanya untuk pembelian minimal } 100 \text { Dus untuk } \\
\text { mendapatkan potongan harga }\end{array}$ & 0,12 & 3 & 0,36 \\
\hline $\begin{array}{l}\text { 3. Mudahnya barang yang hilang dengan minimnya pengawasan yang ada dan } \\
\text { Jumlah tenaga karyawan pemasaran yang tidak mencukupi untuk } \\
\text { memasarkan produk yang beraneka ragam yang dimiliki oleh PT. Enseval } \\
\text { Putera Megatrading Tbk Cabang Banjarmasin }\end{array}$ & 0,10 & 2 & 0,20 \\
\hline $\begin{array}{l}\text { 4. Konsumen bosan dengan promosi perusahaan yang sama secara terus } \\
\text { menerus dan tidak adanya variasi }\end{array}$ & 0,09 & 2 & 0,18 \\
\hline Total Kelemahan & & & 1,16 \\
\hline Total & $\mathbf{1 , 0 0}$ & & 2,81 \\
\hline
\end{tabular}

Tabel 2. Eksternal Factory Analysis Summary (EFAS) 4P Hydro Coco PT. Enseval Putera Megatrading Tbk Cabang Banjarmasin

\begin{tabular}{|c|c|c|c|}
\hline Faktor strategi Eksternal & Bobot & Rating & $\begin{array}{c}\text { Skor } \\
\text { (B X R) }\end{array}$ \\
\hline \multicolumn{4}{|l|}{ Peluang (Oppurtinity): } \\
\hline $\begin{array}{l}\text { 1. Minuman isotonik yang memiliki banyak manfaat seperti mengandung } \\
\text { vitamin, bebas lemak, bernutrisi dan membantu pencernaan. }\end{array}$ & 0,12 & 4 & 0,48 \\
\hline $\begin{array}{l}\text { 2. Dengan memberikan keringanan pembayaran, banyak pelanggan membeli } \\
\text { secara partai }\end{array}$ & 0,12 & 4 & 0,48 \\
\hline $\begin{array}{l}\text { 3. Dengan memiliki gudang yang luas, memudahkan dan mempercepat proses } \\
\text { distribusi }\end{array}$ & 0,09 & 3 & 0,27 \\
\hline 4. Membuka target atau jangkauan promosi baru yang lebih luas & 0,10 & 3 & 0,30 \\
\hline Total Peluang & & & $\mathbf{1 , 5 3}$ \\
\hline \multicolumn{4}{|l|}{ Ancaman (Threats): } \\
\hline $\begin{array}{l}\text { 1. Munculnya produk sejenis Pocari Sweet yang diproduksi bukan dari PT. } \\
\text { Enseval Putera Megatrading }\end{array}$ & 0,08 & 3 & 0,24 \\
\hline $\begin{array}{l}\text { 2. Resiko pelanggan yang nakal setelah orderan barang diterima, membuat } \\
\text { perusahaan menindak lanjuti dengan menyerahkan kepada pihak berwajib } \\
\text { yang memakan waktu dan biaya tambahan }\end{array}$ & 0,09 & 3 & 0,27 \\
\hline 3. Pelanggan yang telat membayar & 0,08 & 2 & 0,16 \\
\hline $\begin{array}{l}\text { 4. Daya beli masyarakat yang menurun karena sering berjalannya waktu nama } \\
\text { perusahaan ini akan hilang karena tertinggal oleh para pesaingnya yang telah } \\
\text { mempromosikan produknya dengan anggaran yang besar }\end{array}$ & 0,09 & 3 & 0,27 \\
\hline Total Ancaman & & & $\mathbf{0 , 9 4}$ \\
\hline Total & 1.00 & & 2,47 \\
\hline
\end{tabular}


Dari kedua matriks diatas, maka diperoleh total EFAS dan IFAS yang akan digunakan dalam pembuatan diagram analisis SWOT. Berikut ini adalah cara menyusun diagram analisis SWOT:

1. Jumlah dari hasil perkalian (B) $\mathrm{x}$ (R) pada peluang dan ancaman diselisihkan untuk mendapatkan titik Y

$\begin{array}{ll}\text { Peluang } & : 1,53 \\ \text { Ancaman } & : 0,94 \\ \text { Titik Y } & : \text { Peluang - Ancaman } \\ & : 1,53-0,94 \\ & : 0,59\end{array}$

2. Jumlah dari hasil perkalian (B) $\mathrm{x}(\mathrm{R})$ pada kekuatan dan kelemahan diselisihkan untuk mendapatkan titik X

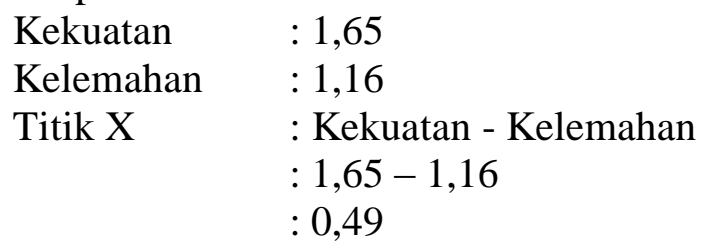

3. Jadi, posisi Hydro Coco pada PT. Enseval Putera Megatrading Tbk Cabang Banjarmasin terletak pada titik $(0.49 ; 0.59)$

Untuk lebih jelasnya, diagram SWOT dapat dilihat pada gambar 1.

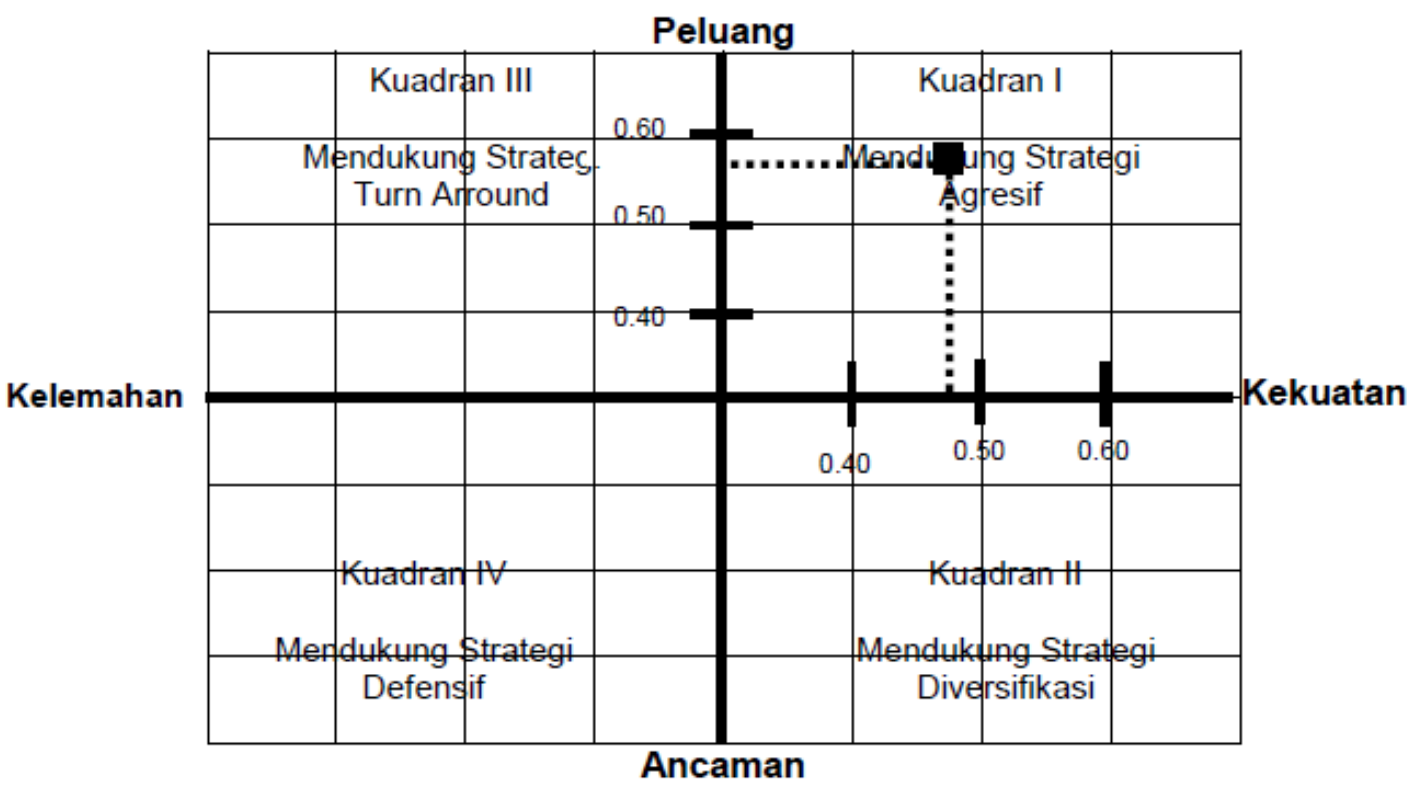

\section{Gambar 1. Diagram SWOT}

Berdasarkan diagram analisis SWOT diatas, dapat disimpulkan bahwa PT. Enseval Putera Megatrading Tbk Cabang Banjarmasin berada dalam kuadran 1 (satu) yaitu mendukung strategi 
agresif, dimana PT. Enseval Putera Megatrading Tbk Cabang Banjarmasin dapat memanfaatkan peluang yang ada didalam perusahaan meliputi:

1. Meningkatkan promosi produk ke seluruh daerah

2. Memanfaatkan kemajuan teknologi untuk lebih dekat kepada konsumen dan distributor

3. Memelihara mutu pelayanan yang baik kepada pelanggan perusahaan

4. Memberikan potongan harga

Berdasarkan analisis faktor internal dan eksternal PT. Enseval Putera Megatrading Tbk Cabang Banjarmasin, maka dapat disusun beberapa alternatif strategi berdasarkan analisis matrik SWOT sebagai berikut:

1. Strategi SO (Strenghts-Oppurtinity)

Strategi ini adalah untuk memanfaatkan seluruh kekuatan untuk merebut dan memanfaatkan peluang sebesar-besarnya. Strategi yang dapat digunakan yaitu:

a. Dengan memiliki kekuatan produk unggulan dari PT. Enseval Putera Megatrading Tbk Cabang Banjarmasin yaitu Hydro Coco dan dengan melihat peluangnya yaitu minuman Hydro Coco dari PT. Enseval Putera Megatrading Tbk Cabang Banjarmasin merupakan minuman air kelapa pertama dalam kemasan $250 \mathrm{ml}$ dan $500 \mathrm{ml}$ serta memiliki 7 kebaikan didalamnya, saran untuk perusahaan yaitu mempertahankan kualitas yang telah ada karena telah memiliki kekuatan yang baik (Strategi SO)

b. Kekuatan dari perusahaan yaitu pembayaran bisa mundur sampai dua minggu dan dengan melihat peluangnya yaitu memberikan keringanan pembayaran, banyak para pelanggan membeli secara partai, saran untuk perusahaan yaitu fokus pada pelanggan untuk mendongkrak sales perusahaan (Strategi SO)

c. Kekuatan perusahaan dalam promosi yaitu para sales man langsung terjun ke konsumen serta reseller dan dengan melihat peluannya yaitu membuka target baru atau jangkauan promosi baru yang lebih luas, perusahaan lebih mudah untuk mempromosikan ke wilayah pasar yang baru (Strategi SO).

d. Dengan memiliki kekuatan tempat dan distribusi yaitu perusahaan memiliki gudang yang luas dibeberapa kota dan dengan melihat peluangnya yaitu mempermudah dan mempercepat proses distribusi, saran untuk perusahaan yaitu menambah gudang di kota-kota yang belum ada sebelumnya, untuk lebih mempercepat proses distribusi (Strategi SO)

\section{Strategi WO (Weakness-Oppurtinity)}

Strategi ini diterapkan berdasarkan pemanfaatan peluang yang ada dengan cara meminimalkan kelemahan yang ada. Strategi yang dapat digunakan yaitu:

a. Dilihat dari segi kelemahan dengan peluang, maka saran untuk perusahaan yaitu memperbaiki kualitas kemasan agar tidak mudah pecah (Strategi WO).

b. Dilihat dari segi kelemahan dengan peluang, maka saran untuk perusahaan adalah memberikan potongan harga untuk reseller dengan pembelian secara partai dan cash (Strategi WO).

c. Dilihat dari segi kelemahan dan peluang, maka perusahaan disarankan untuk memberikan promosi dalam bentuk program undian berhadiah langsung kepada konsumen berupa barang elektronik, umroh atau perhiasan (Startegi WO).

d. Dilihat dari segi kelemahan dan peluang, maka saran untuk perusahaan yaitu menambah pegawai di tiap-tiap gudang nya untuk mencatat stok yang ada (Strategi WO) 


\section{Strategi ST (Strenghts-Threaths)}

Strategi ini adalah untuk menggunakan kekuatan yang dimiliki perusahaan untuk mengatasi ancaman. Strategi yang dapat digunakan yaitu:

a. Dari segi kekuatan dengan ancamannya yaitu munculnya produk sejenis, disarankan untuk mempertahankan kualitas produk untuk menjaga eksistensi dari produk Hydro Coco menjangan (Strategi ST).

b. Dari segi kekuatan dengan ancaman yaitu reseller yang kabur, maka perusahaan untuk memantau perkembangan dari tiap-tiap reseller, untuk mengindari reseller yang kabur (Strategi ST)

c. Dari segi kekuatan dengan ancamannya yaitu seiring berjalannya waktu nama perusahaan ini akan hilang karena tertinggal oleh para pesaingnya yang telah mempromosikan melalui anggaran yang lebih besar, maka saran untuk perusahaan yaitu lebih gencar melakukan promosi dengan menambah jumlah salesman di beberapa daerah (Strategi ST).

d. Dari segi kekuatan dengan ancaman perusahaan yaitu mudahnya barang yang hilang dengan minimnya pengawasan yang ada, saran untuk perusahaan adalah menambah karyawan dan satpam di tiap-tiap gudang (Strategi ST)

\section{4. $\quad$ Strategi WT (Weakness- Threaths)}

Strategi ini didasarkan pada kegiatan perusahaan yang bersifat defensif dan berusaha meminimalkan kelemahan yang ada serta menghindari ancaman. Strategi yang dapat dilakukan yaitu:

a. Dari segi ancaman dengan kelemahan perusahaan, yaitu kemasan mudah rusak atau bocor, disarankan perusahaan untuk memperbaiki kualitas kemasan dan desain untuk membuat konsumen lebih tertarik (Strategi WT)

b. Dari segi ancaman dengan kelemahan perusahaan, yaitu pembelian harus secara partai untuk mendapatkan potongan harga, disarankan perusahaan untuk memberikan bonus kepada reseller yang telah lama dan di percaya oleh perusahaan (Strategi WT)

c. Dari segi ancaman dengan kelemahan perusahaan, yaitu konsumen bosan dengan promosi perusahaan yang sama secara terus menerus dan tidak adanya variasi, disarankan perusahaan untuk melakukan promosi secara periodik pada pasar (Strategi WT)

d. Dari segi ancaman dengan kelemahan perusahaan, yaitu kesalahan data stok barang yang ada di tiap-tiap gudang karena kurangnya pegawai, saran untuk perusahaan yaitu menambah karyawan di tiap-tiap gudang dan menggunakan teknologi CCTV (Strategi WT)

\section{Kesimpulan}

1. Strategi pemasaran yang diterapkan PT. Enseval Putera Megatrading Tbk Cabang Banjarmasin pada minuman Isotonik Hydro Coco dapat dikatakan belum efektif, hal ini dapat diketahui dari omzet penjualan Hydro Coco di Kota Banjarmasin pada tahun 20152017 mengalami penurunan. Dimana perusahaan menerapkan strategi 4P meliputi produk yang dijual terdiri dari kemasan $250 \mathrm{ml}$ dan $500 \mathrm{ml}$, harga ditawarkan dengan tingkatan berbeda (grosir, retail dan toko), tempat berada di Jalan Jenderal Ahmad Yani KM.21 Kabupaten Banjar yang mempunyai gudang yang berukuran cukup besar dan promosi dilakukan melalui iklan dan promosi penjualan.

2. Strategi pemasaran yang tepat agar produk minuman Isotonik Hydro Coco dapat meningkat melalui analisis SWOT, dimana hasil analisis yang dilakukan menunjukkan posisi Hydro 
Coco pada PT. Enseval Putera Megatrading Tbk Cabang Banjarmasin terletak pada titik $(0.49$; 0.59) sehingga strategi yang digunakan adalah meningkatkan promosi produk ke seluruh daerah, memanfaatkan kemajuan teknologi untuk lebih dekat kepada konsumen dan distributor, memelihara mutu pelayanan yang baik kepada pelanggan perusahaan, memberikan potongan harga

3. PT. Enseval Putera Megatrading Tbk Cabang Banjarmasin hendaknya mempertahankan produk yang ada dengan menjaga kualitas dan pengawasan terhadap pengiriman ke pihak distributor (toko, supermarket, minimarket, dan lain sebagainya) agar tidak ada kerusakan dalam pengirimannya.

4. PT. Enseval Putera Megatrading Tbk Cabang Banjarmasin hendaknya memberikan garansi produk terhadap harga yang ada yaitu dengan memberikan jaminan terhadap kualitasnya.

5. PT. Enseval Putera Megatrading Tbk Cabang Banjarmasin sebaiknya dapat menjadi sponsor dalam kegiatan promosi yang dilaksanakan seperti pertandingan olahraga.

6. Distribusi hendaknya perlu ditingkatkan agar dapat memberikan rasa aman dan nyaman bagi distributor yang datang ke kantor PT. Enseval Putera Megatrading Tbk Cabang Banjarmasin seperti penjagaan di pos, CCTV dan lain sebagainya.

\section{DAFTAR PUSTAKA}

Agus Athori, 2017, Analisis Strategi Pemasaran Dalam Meningkatkan Penjualan Produk Pada Perusahaan Snack Olympic Kediri. Skripsi

Alma, Buchari, 2015, Perilaku Konsumen Pemahaman Dasar dan Aplikasinya Dalam Strategi Pemasaran. Bali: Universitas Udayana.

Assauri, Sofyan, 2013, Perencanaan Strategis Pemasaran Untuk Menciptakan Sustainable Competitive Advantage, Yogyakarta: Andi Pusaka

Huriyati, 2015, Manajemen Pemasaran, Pusaka Baru, Jakarta

Kasali, Ridwan, 2013, Manajemen Pemasaran (Analisis, Perencanaan, Pelaksanaan dan Pengendlian). Bandung: Linda Karya.

Kotler, Philip dan Kevin Lane Keller. 2014. Manajemen Pemasaran. Jilid Satu, Edisi kedua belas. Cetakan Ketiga: PT. Indeks.

Laksana, Fajar, 2013, Manajemen Pemasaran, Yogyakarta: Graha Ilmu.

Lupiyoadi, 2013, Manajemen Pemasaran. Jakarta: Prenhalindo

Machfoedz, 2014, Pemasaran : Substansi Manajemen, Liberty, Jakarta

Nur Afrilita T, 2016, Strategi Pemasaran Dalam Meningkatkan Penjualan Produk Frestea di Samarinda, Skripsi.

Ramli, Muhammad, 2013, Konsep dan Strategi Pemasaran Perusahaan Jasa, Pusaka Baru, Jakarta

Saladin, Djaslim, 2013, Manajemen Pemasaran. Bandung: Linda Karya

Tjiptono, Fandi, 2015, Strategi Pemasaran. Edisi kedua. Cetakan ketujuh. Yogyakarta: Andi Pusaka

Zagladi, Arief Noviarakhman, Fredy Jayen, Sutrisno dan Melania, 2017, Pedoman Penulisan Skripsi STIE Pancasetia Banjarmasin, Pancasetia, Banjarmasin 